\title{
Sources of Market Information, Its Quality and New Product Financial Performance
}

\author{
Dariusz Dabrowski
}

\author{
Gdansk University of Technology \\ ul. G. Narutowicza 11/12, 80-233 Gdansk, Poland \\ E-mail.ddab@zie.pg.gda.pl
}

cross $^{\text {ref }}$ http://dx.doi.org/10.5755/j01.ee.29.1.13405

\begin{abstract}
While we observe a growing interest in the role of market information in new product development (NPD), existing research has still largely ignored the quality of market information that is a crucial issue in the era of the information society. What does affect the quality of market information in new product development projects, and how does this quality influence the financial performance of new products? In this paper, we address these questions and hypothesize that sources of information (e.g. customers, competitors) influence the quality of market information, and this quality affects new product financial performance through market predictability as a mediator. We test these hypotheses using data of about 287 new product projects of medium-high and high technology firms from Poland. Our findings indicate that the key sources that influence market information quality are customers and competitors. More intensive collection of market information from these two sources, and especially from customers, will result in this information being of a higher quality. Surprisingly, gathering market information from other market entities (e.g. suppliers, distributors) has no effect on the quality of market information. We also find that an important consequence of high quality market information available in NPD is high new product financial performance. Additionally, market information quality positively influences market predictability that, in turn, has a positive impact on new product performance. Our results support a partial mediation effect of market predictability between the quality of market information and NPD financial performance. Based on these findings, the author discusses the theoretical and managerial implications of this work and proposes paths for future research.
\end{abstract}

Keywords: Market Information Quality; Sources of Market Information; New Product Performance; NPD, Market Information; New Product Development.

\section{Introduction}

Nowadays, information is regarded as quite important as a resource in economics, because it is seen as one of the additional, non-traditional factors of production (Warr \& Ayres, 2012). Traditional factors of production are land, labour and capital, and this list is being expanded with new non-traditional factors (e.g. information) that are important for economic growth. Utilizing information in an enterprise has economic consequences that are reflected in a company's turnover and profits (Ruzevicius \& Gedminaite, 2007).

One important application of information in a company is in manager's decision process. Every decision is based on information. However, in the area of economics of information, it is recognized that information can be of differing quality (Birchler \& Butler, 2017). To take a good decision, high quality of information is needed, and, in this way, managers' decisions heavily rely on the quality of information available (Hultink, Talke, Griffin, \& Veldhuizen, 2011; Kuo \& Lee, 2009; Naicker \& Jairam-Owthar, 2017). However, on the one hand, the quality of information may depend on its source (Woudstra, Van Den Hooff, \& Schouten, 2012; Zha et al., 2018), and on the other hand, the quality of information available for managers is likely to influence the economic results of different activities of a firm (Ruzevicius \& Gedminaite, 2007; Sagawa \& Nagano, 2015).

This is particularly apparent in the case of market information that is used in new product development. Market information is concerned with a company's environment, and its quality can vary with regard to the source of information. However, this kind of information is a crucial resource when developing new products. The voice of the customer, or even broadly the voice of the market, has to be taken into account at each stage of the new product development process, so the new product can meet customers' needs and desires better than competing products (Barczak, Griffin, \& Kahn, 2009; Cooper, Edgett, \& Kleinschmidt, 2004; Drejeriene \& Drejeris, 2017; Kahn et al., 2012). Managers' decisions about product functions and attributes, and about marketing activities pursued during commercialization (e.g. distribution channels, promotional programmes) are based on the market information available. However, the economic effects of a new product - expressed in terms of turnover or profits - will depend on the quality of this information. This reasoning shows the importance of market information quality in new product development (Hultink et al., 2011).

To date, there is scientific evidence that the quality of information is in line with new product performance (Hultink et al., 2011), but little is known about the antecedents of quality of market information as well as other consequences of using it. To discover both, the predecessors and the effects of the quality of market information are important. The former determines the quality of the information and influences the economic performance of a product through this; the latter can work as mediators between information quality and product success.

In this work, we examine this problem and presume that, firstly, sources of acquiring market information are the key 
antecedents of market information quality within new product development. Secondly, market predictability is a consequence of the quality of market information, and it mediates between this quality and the financial success of a new product. This problem is tackled in the case of mediumhigh and high technology companies as they are heavily engaged in new product development.

Therefore, the scientific problem undertaken in this research can be expressed as follows: (1) what is the relationship between different sources of obtaining market information and its quality? (2) Does market predictability mediate between market information quality and new product financial performance? Therefore, in this work we concentrate on market information (as an inputting factor in NPD process that comes from different sources), quality of market information available in NPD, and economic results of such input.

Consequently, the aim of this article is to examine: (1) the relationship between different sources of obtaining market information and its quality within new product development, as well as (2) the mediating effect of market predictability between market information quality and new product financial success among medium-high and high technology Polish companies that employ more than 49 people.

The research method applied is a quantitative research study. Data have been gathered through a survey conducted on a random sample of the population of interest. Altogether, 287 cross-sectional data sets of product innovation projects have been analysed by applying structural equation modelling.

The novelty of the article comes from several aspects. Firstly, different sources of gathering market information so far have not been investigated as the predecessors of market information quality, especially in the area of new product development. Secondly, the mediating effect of market predictability - between market information quality and new product financial performance - has not been studied. Both issues are important aspects of the quality of market information, predominantly in the quite risky area of product development. Thirdly, a structural model has been developed that incorporates both the antecedents and consequences of market information quality so the phenomenon will be explained in a complex manner within the scope of the work.

The remainder of the article is arranged as follows. Firstly, the pertinent literature is reviewed - i.e. the relationships among sources of gathering market information and market information quality, and between this quality and market predictability as well as new product performance and specific hypotheses are developed. Secondly, the research methods used are described. Thirdly, the analysis is explained and our results are presented. Lastly, the implications of the results are drawn as well as limitations and suggestions for future research.

\section{Theoretical Framework and Hypotheses Key Terms and Theoretical Background}

From the point of view of this paper, two important terms should be defined. The first is 'market information', and the second is 'the quality of market information'. C. Moorman defines 'market information' as 'data concerned with a firm's current and potential external stakeholders' (Moorman, 1995, p. 319). According to this definition, by market information we mean information about different entities in the company's market environment, for example about customers, competitors or distributors.

Next, the term of 'market information quality' can be defined in accordance with the essence of quality, which is to satisfy the expectations of users (Ruzevicius \& Gedminaite, 2007). On this basis, market information quality means meeting users expectations (Lillrank, 2003). These expectations can be fulfilled to a certain extent, so the quality can differ from very low to very high. Users of market information, in the case of new product development, are people who are engaged in product innovation projects, for example those involved in a new product team, so their expectations are valid in this situation. One approach of expressing quality of information is to list appropriate attributes or dimensions of information, such as reliability, completeness, relevancy or timeliness (Lillrank, 2003). This approach is quite popular and is used to measure the quality of information (Hultink et al., 2011; Lee, Strong, Kahn, \& Wang, 2002; Li \& Lin, 2006; Low \& Mohr, 2001; Ruzevicius $\&$ Gedminaite, 2007).

The theoretical background for this study comes from the resource-based view (RBV) of the firm. RBV theory states that a company's performance depends on possessing and utilizing firm-specific resources. Valuable and rare resources lead a company to a competitive advantage that can be temporary, but if these resources are not imitated and substituted by competitors, they will ensure the superior longterm performance of a firm (Barney, 1991; Henard \& McFadyen, 2012; Wade \& Hulland, 2004). According to existing conceptions, firm resources include all assets, capabilities, organizational processes, firm attributes, information, knowledge and others (Barney, 1991). These resources can be either tangible (e.g. machinery, materials) or intangible (e.g. brand equity, information) (Henard \& McFadyen, 2012).

\section{Research Model and Hypotheses}

As in (Durmusoglu \& Barczak, 2011) and (Henard \& McFadyen, 2012), we apply the RBV theory in the field of new product development. Therefore, it is assumed that utilization of a firm's unique resources in the area of new product development will lead to high new product performance (Henard \& McFadyen, 2012). This study concentrates on two critical resources of new product development, the first being market information and its quality, and the second being sources of obtaining market information. Market information, and especially information of high quality, is a critical intangible asset for new product development (Cooper et al., 2004). Using high quality information about the market for a new product will result in proper managerial decisions, and therefore will provide at least a competitive advantage for a firm (Hultink et al., 2011). On the other hand, sources of obtaining market information create unique firm capabilities (Wade \& Hulland, 2004). If a company's sources of market information are able to provide information of high quality for new product managers, this can lead, not only to competitive advantage, but also to longterm, superior new product performance. 
Figure 1 presents the research model that includes the constructs under consideration: sources of obtaining market information, market information quality, market predictability and new product financial performance.

The central point of the model is market information quality (Qua) that, on the one hand, depends on different sources of gaining information, and on the other hand, utilizing this information will result in market predictability as well as high new product performance (Hultink et al., 2011). Sources of obtaining market information have not been empirically tested so far as antecedents of its quality; however, sources of information impact its quality (Ruzevicius \& Gedminaite, 2007). In our study, we take into account three basic sources of market information, namely customers (Cus), competitors (Com) and other entities (Oth) such as distributors, suppliers, industry institutions or independent experts. Each of these sources is able to provide good market information; therefore, we assume that if more information is gathered from each source, higher information quality will result. Hence, we propose that:

Gathering market information from customers (Hla), competitors (H1b) and other entities (H1c) positively affect market information quality.

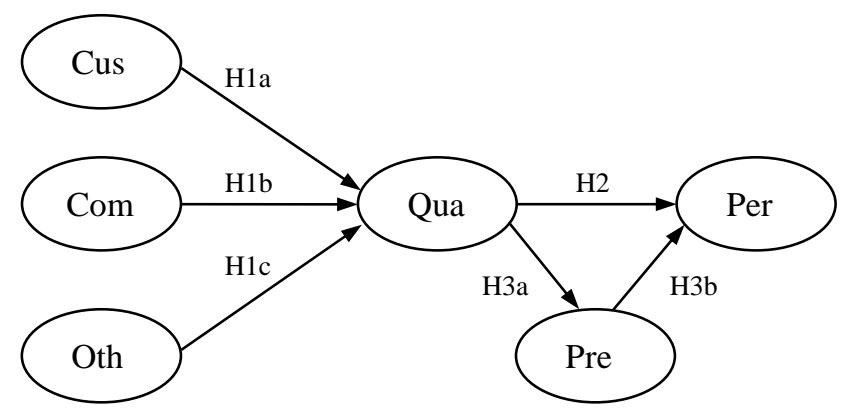

Figure 1. Conceptual Research Model

Previous research has already proved that market information quality and market predictability are associated with new product performance (Hultink et al., 2011), but the mediating effect of market predictability between both constructs has not been studied. Our logic is that high quality of market information yields better market predictability (Pre), and this, in turn, leads to high new product financial performance (Per). Hence, we propose that:

Market information quality has a positive effect on new product financial performance ( $\mathrm{H} 2)$.

Market information quality affects market predictability $(H 3 a)$, and the latter has a positive effect on new product financial performance $(\mathrm{H} 3 \mathrm{~b})$.

\section{Research Methods \\ Sample and Data Collection}

Data were gathered in Poland through a cross-sectional mail survey among high-tech and medium high-tech firms. These companies have been chosen as they are heavily engaged in new product development. Furthermore, in this group, technological and market aspects change more quickly than in lower technology firms, and products of firms from this group are more complex and require more market information than simpler products.
Our sampling frame consisted of companies that employed more than 49 workers within both high-tech industries, such as computers and electronics, pharmaceutical, aerospace as well as medium high-tech industries, such as chemical, electrical industrial machinery, automotive, medical appliances and others. A list of such companies was obtained from the HBI database. We randomly chose 792 firms from the sampling frame and they were asked to participate in our study.

When collecting data, we applied a quite popular approach in the new product development field that relies on asking about successful and unsuccessful new products (Danneels \& Kleinschmidt, 2001; Garcia, Sanzo, \& Trespalacios, 2008; Millson, 2015). For each company, two versions of the same questionnaire were sent out: one related to product success, and the second to product failure. Questionnaires were directed to the person with the highest position in the firm (e.g. managing director). The recipient was asked to select two new products that had been launched at least six months before receiving our mail and to direct the relevant questionnaires to people involved in these projects. To increase the response rate, we sent two follow-up letters, each a week later than the previous mail. The first mailing package included a personalized letter, both versions of the questionnaire and a return addressed envelope. In the last mailing wave, we sent the questionnaires again. Our questionnaire had been tested in a pilot study that included fifteen new product professionals, before mailing it to the companies.

A total of 165 firms participated in the survey, and the rate of return was 20.8 percent. Altogether, we received 287 valid questionnaires, among them 154 related to successful and 133 to unsuccessful new products.

The structure of our sample with regard to size was as follows: companies employing from 50 to 250 people accounted for 70.8 percent, those which had from 250 to 999 people -9.9 percent, while other companies accounted for 9.9 percent.

\section{Measurement}

As in other studies on processing market information within NPD (Hultink et al., 2011), the unit of analysis in this study is the NPD project because market information obtained within a particular development is a project specific, for example in the case of customer needs, market competition or market demand. Consequently, in the questionnaire, the informants were asked to reflect upon a NPD project.

We designed a questionnaire to measure the constructs included in our conceptual model. Each construct was measured using a multiple items reflective scale. For each item, Likert type statements were used with a five-point scale ranging from 'totally disagree' to 'totally agree'.

We developed four items for each construct used to measure gathering of market information from the three sources - i.e. customers, competitors, or other entities. The items were designed in such a way as to cover the essential content of each construct (Hair, Black, Babin, \& Anderson, 2014).

The quality of market information was measured using four items. Following other studies related to information 
quality (Hultink et al., 2011; Low \& Mohr, 2001), we distinguished four key dimensions. These were: reliability, completeness, relevancy and timeliness. Each of these dimensions was measured by using a single item (Hultink et al., 2011) and (Low \& Mohr, 2001).

The new product financial performance construct was a four multi-item scale and market predictability construct including three items. The items of these constructs were borrowed from (Hultink et al., 2011). All product performance items are considered as financial measures of new product success (Hertenstein \& Platf, 2000).

\section{Analysis and Results Measurement Model Assessment}

Firstly, for each measure, a principal component analysis (PCA) was conducted, where only the first eigenvalue was greater than one. This resulted in obtaining only one factor for each construct, hence providing evidence that each construct is unidimensional.

Then we performed confirmatory factor analysis (CFA), thus restricting the entire set of items to load on their respective a priori specified factors (Brown, 2015). According to (Hair et al., 2014) our sample size of 287 units can be considered as sufficient to evaluate a CFA model with regard to its complexity (i.e. only six factors) as well as basic characteristics (i.e. ninety percent of modest and high item communalities and no underidentified factors). CFA was performed using Mplus v. 7.11 with the maximum likelihood and mean-adjusted estimator (MLM) that is robust to data non-normality (Muthen \& Muthen, 2012). The results are satisfactory. The measurement model has an acceptable level of fit to the data: $\chi^{2}(215)=367,175, p<0.0001$, SRMR $=$ 0.045, RMSEA $=0.050, \mathrm{TLI}=0.954, \mathrm{CFI}=0.961$. The critical value of RMSEA (Root Mean Square Error of Approximation) equals 0.06 (Hu \& Bentler, 1999) and our result does not exceed this; the coefficients TLI (Tucker Lewis Index) and CFI (Comparative Fit Index) should not be lower than 0.95 (Hu \& Bentler, 1999), and this condition is met. In addition, the ratio of the coefficient $\chi^{2}$ to the number of degree of freedoms is 1.71 , and does not exceed the critical value of 3 (Hair et al., 2014). The standardized loadings of all measurement items are highly significant (the smallest $t$ value is 11.81) and load on their construct with a value of at least 0.5 (Hair et al., 2014), which demonstrates adequate convergent validity. Table 1 presents the measurement items, their standardized loadings, and t-values.

Correlations are shown in Table 2 together with construct reliabilities (CR) and the square root of average variance extracted (AVEs) of the constructs. As can be seen, all values of construct reliabilities are above the acceptable level of 0.6 (Hair et al., 2014). Furthermore, in each construct, the squareroot of the AVE is larger than the highest correlation between constructs involving the focal construct, thus indicating the constructs have discriminant validity (Fornell \& Larcker, 1981).

Table 1

Confirmatory Factor Analysis (CFA) Results

\begin{tabular}{|c|c|c|c|}
\hline Construct & Items & $\begin{array}{l}\text { Std. factor } \\
\text { loading }\end{array}$ & $\begin{array}{c}\text { t- } \\
\text { Value }\end{array}$ \\
\hline $\begin{array}{l}\text { Gathering market } \\
\text { information from } \\
\text { customers (Cus) }\end{array}$ & $\begin{array}{l}\text { During the NPD project ... } \\
\text { - We gathered market information from potential buyers. } \\
\text { - Target customers were a source of information about their needs. } \\
\text { - We gathered market information on different stages of NPD. } \\
\text { - We obtained market information several times from future customers. }\end{array}$ & $\begin{array}{l}0.724 \\
0.683 \\
0.732 \\
0.821\end{array}$ & $\begin{array}{l}22.85 \\
15.65 \\
21.40 \\
24.57\end{array}$ \\
\hline $\begin{array}{l}\text { Gathering market } \\
\text { information from } \\
\text { competitors } \\
(\mathrm{Com})\end{array}$ & $\begin{array}{l}\text { During the NPD project ... } \\
\text { - We gathered market information from potential competitors (e.g. at fairs, meetings or through } \\
\text { personal contacts). } \\
\text { - We analysed competitive products to the new product. } \\
\text { - Web sites of prospective competitors, their materials and promotional activities were a source of } \\
\text { information about them. } \\
\text { - We observed the behaviour of prospective competitors. }\end{array}$ & $\begin{array}{l}0.579 \\
0.756 \\
0.777 \\
0.664\end{array}$ & $\begin{array}{l}11.81 \\
18.15 \\
21.75 \\
16.82\end{array}$ \\
\hline $\begin{array}{l}\text { Gathering market } \\
\text { information from } \\
\text { other entities } \\
\text { (Oth) }\end{array}$ & $\begin{array}{l}\text { During the NPD project ... } \\
\text { - Other market entities (e.g. intermediaries, suppliers, trade associations, experts) were a source of } \\
\text { information about the market for this product. } \\
\text { - Through these other entities we have gained information about future buyers and competitors. } \\
\text { - We contacted the other entities several times to gain information about the market. } \\
\text { - We obtained a lot of market information from these entities. }\end{array}$ & $\begin{array}{l}0.794 \\
0.839 \\
0.875 \\
0.856\end{array}$ & $\begin{array}{l}30.48 \\
32.90 \\
44.79 \\
37.49 \\
\end{array}$ \\
\hline $\begin{array}{c}\text { Market } \\
\text { information } \\
\text { quality (Qua) }\end{array}$ & $\begin{array}{l}\text { Market information that was available during the NPD project ... } \\
\text { - Was true. } \\
\text { - Was sufficient to our needs. } \\
\text { - Was useful. } \\
\text { - Was timely. }\end{array}$ & $\begin{array}{l}0.807 \\
0.760 \\
0.808 \\
0.684\end{array}$ & $\begin{array}{l}30.10 \\
30.92 \\
33.81 \\
17.59 \\
\end{array}$ \\
\hline $\begin{array}{c}\text { Market } \\
\text { predictability } \\
\text { (Pre) } \\
\end{array}$ & $\begin{array}{l}\text { - Developments in the new product market were predictable. } \\
\text { - Changes in customers' preferences for this product were predictable. } \\
\text { - Customers' future needs were predictable. }\end{array}$ & $\begin{array}{l}0.788 \\
0.929 \\
0.812\end{array}$ & $\begin{array}{l}22.80 \\
46.86 \\
23.29\end{array}$ \\
\hline $\begin{array}{l}\text { New product } \\
\quad \text { financial } \\
\text { performance (Per) }\end{array}$ & $\begin{array}{l}\text { The new product attained ... } \\
\text { - Quantitative sales goals. } \\
\text { - The growth in revenue sales goals. } \\
\text { - Market share goals. } \\
\text { - Sufficient sales as a percentage of company sales. }\end{array}$ & $\begin{array}{l}0.957 \\
0.936 \\
0.907 \\
0.884\end{array}$ & $\begin{array}{l}112.98 \\
68.87 \\
56.33 \\
58.87\end{array}$ \\
\hline
\end{tabular}

$\left(\chi^{2}(398)=671,540, p<0.0001 ; \mathrm{SRMR}=0,044 ; \mathrm{RMSEA}=0.049 ; \mathrm{TLI}=0.950 ; \mathrm{CFI}=0.957 ; \chi^{2} / d f=., 69\right)$ 
Construct Correlations, Reliability and Validity Coefficients

\begin{tabular}{|c|cccccc|c|c|}
\hline Construct & Cus & Com & Oth & Qua & Pre & Per & AVE & 0.550 \\
Cus & 0.742 & & & & 0.829 \\
Com & 0.341 & 0.699 & & & 0.490 \\
Oth & $0.215^{*}$ & 0.351 & 0.841 & & 0.790 \\
Qua & 0.523 & 0.366 & $0.200^{*}$ & 0.766 & & 0.907 \\
Pre & 0.258 & $0.179^{*}$ & $0.162^{*}$ & 0.519 & 0.845 & 0.904 \\
Per & 0.435 & 0.251 & 0.212 & 0.674 & 0.635 & 0.921 & 0.703 \\
\end{tabular}

Off-diagonal: construct correlations; along-diagonal: square root of AVE. ${ }^{*} p<0.01$; in other cells $p<0.001$. Abbreviations of constructs as given in Table 1.

Overall, the preceding analyses and results indicate acceptable properties within the measurement model.

\section{Hypothesis Testing}

After validation of the measurement model, we estimated (Kline, 2016) the structural model in Figure 1. We performed structural equation modelling (SEM) using Mplus v. 7.11 applying the MLM method of estimation. The overall goodness-of-fit statistics show that the structural model fits the data well: $\chi^{2}(221)=374,121, p<0.0001$, SRMR $=0.049$, $\mathrm{RMSEA}=0.049(90 \% \mathrm{CI}=0,040-0,058), \mathrm{TLI}=0.955, \mathrm{CFI}$ $=0.961$. The values of all of these indices are in acceptable ranges. Furthermore, the ratio of coefficient $\chi^{2}$ to the number of degree of freedoms does not exceed the critical value of 3 (Hair et al., 2014) as it is equal to 1.69 .

The model presented in Figure 1 assumes partial mediation of market predictability between market information quality and new product financial performance. All correlations between the three constructs were significant; therefore, we also evaluated an alternative model that included full mediation (Hair et al., 2014), i.e. without the direct effect between market information quality and new product performance constructs. The results were worse because the model did not fit well to the data: $\chi^{2}(222)=$ $434,443, p<0.0001, \mathrm{SRMR}=0.082$, RMSEA $=0.058, \mathrm{TLI}$ $=0.938, \mathrm{CFI}=0.946, \chi^{2} / d f=1.96$. Specifically, the SRMR measure slightly exceeds the cut-off value of 0.08 (Kelloway, 2015), and both TLI as well as CFI indices are below the critical value of 0.95 . The model with full mediation is nested in the model of partial mediation; therefore, we examined the Satorra-Bentler scaled chi-square difference test $\mathrm{T}_{\mathrm{s}}$ (Brown, 2015) used for the MLM estimator (Muthen \& Muthen, 2012). The results showed that the full mediation solution resulted in a significant decrease in model fit $\left(\mathrm{T}_{\mathrm{s}}(1)=110.29\right.$, $d f=222-221=1 s s)$; therefore, the partial mediation model provides a better solution than the full mediation one. These findings support the partial mediation effect of market predictability. Hence, we continued our further analysis with the model as presented in Figure 1 - with partial mediation between the consequences of market information quality and tested our hypotheses.

We evaluated parameter estimates of paths included in the structural model. Figure 2 presents these parameters and significance levels for each path. We found that gathering market information from customers positively influences market information quality $(\beta=0.459, p<0.001)$, thus H1a is supported. Furthermore, our results showed that gathering market information from competitors positively impacts market information quality $(\beta=0.192, p<0.01)$. As a consequence, this finding supports H1b. However, the coefficient linking gathering market information from other entities to market information quality is not significant; therefore, hypothesis $\mathrm{H} 1 \mathrm{c}$ is not supported by our results.

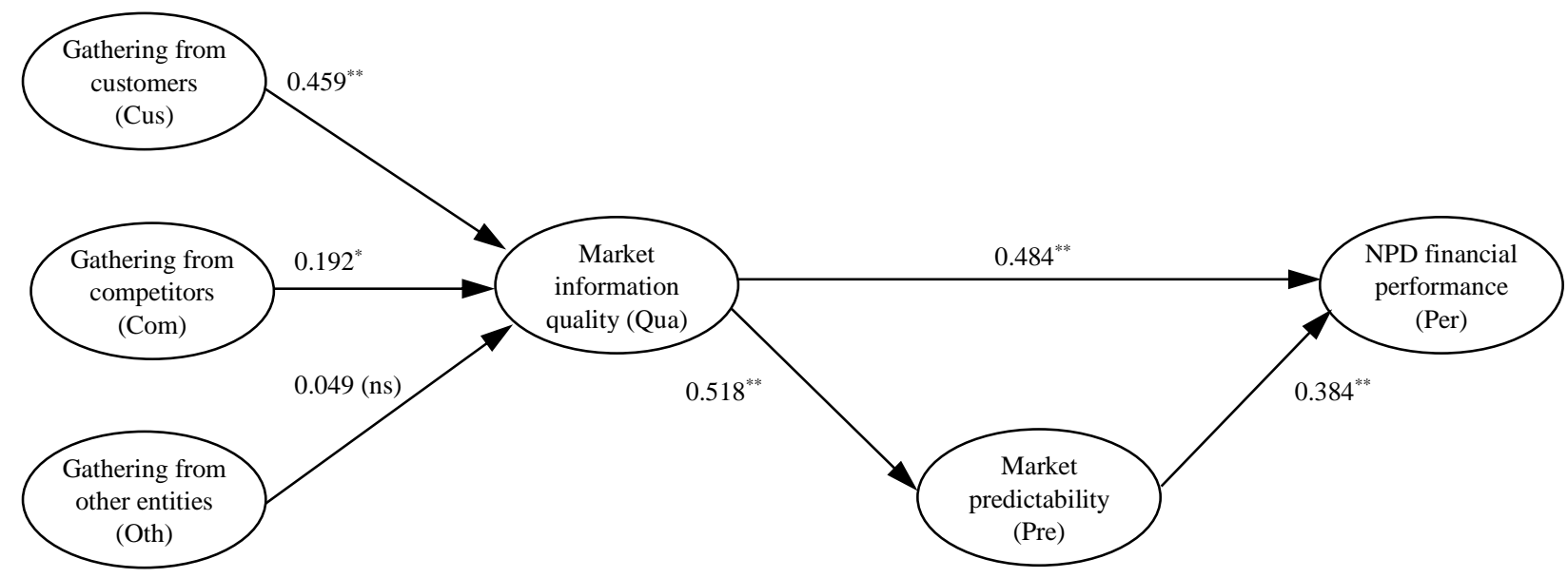

Goodness-of-fit statistics: $\chi^{2}(221)=374,121, p<0.0001$, SRMR $=0.049$, RMSEA $=0.049(90 \%$ CI $=0.040-0.058)$, TLI $=0.955$, CFI $=0.961$ Notes: ${ }^{*} p<0.01,{ }^{* *} p<0.001, \mathrm{~ns}-$ not significant

Figure 2. Results of the Estimation of the Structural Equation Model 
With regard to the consequences of market information quality, we hypothesized a positive effect of market information quality for new product financial performance both directly (H2) and indirectly (H3a, H3b) through market predictability. The findings show that market information quality positively influences new product financial performance directly $(\beta=0.484, p<0.001)$, therefore supporting H2. Furthermore, we found that market information quality positively impacts market predictability as the coefficient linking both constructs is significant and has a positive value $(\beta=0.518, p<0.001)$, thus supporting $\mathrm{H} 3 \mathrm{a}$; we also found market predictability positively impacts new product financial performance $(\beta=0.384, p<0.001)$, hence this result supports $\mathrm{H} 3 \mathrm{~b}$. The indirect effect of market information quality on NPD financial performance via market predictability - that is a product of two simple effects - is positive and significant $(\beta=0.199, p<0.001)$. Overall, our results show a partial mediation effect between the quality of market information and new product financial performance through market predictability. Table 3 presents a summary of the results of the hypotheses tests.

\section{Summary of Results of Hypothesis Testing}

\begin{tabular}{|lc|c|}
\hline \multicolumn{1}{|c|}{ Hypothesis } & Result \\
\hline H1a: Gathering market information from customers positively affects market information quality & Supported \\
H1b: Gathering market information from competitors positively affects market information quality & Supported & Not supported \\
H1c: Gathering market information from other entities positively affects market information quality & Supported & Supported \\
H2: Market information quality has positive effect on new product financial performance & Supported & \\
H3a: Market information quality positively influences market predictability & \\
H3b: Market predictability has positive effect on new product financial performance & \\
\hline
\end{tabular}

\section{Conclusions}

In this work, we have developed a conceptual model that included certain antecedences and consequences of market information quality within new product development projects. On the one hand, we hypothesized that gathering market information from customers, competitors and other entities positively influences market information quality. These kinds of linkages have not been studied so far. On the other hand, we hypothesized that market information quality positively affects new product financial performance directly, as well as indirectly through market predictability that works as a mediator. Such a mediation effect has not been investigated previously. Our conceptual model is based on the idea that market information can be regarded as an input production factor that has an impact on the economic results of NPD.

Our findings indicate that obtaining market information from customers and from competitors in NPD projects positively influences market information quality. An especially strong linkage exists in the case of gathering market information from customers. This result is not surprising, because a new product is developed for customers according to their needs and wants. This kind of intelligence is quite an important part of market information when developing new products, and acquiring it directly from customers increases overall market information quality. Apart from customers, competitors can be considered as a valuable source of high market information in NPD as they try to satisfy the same needs and wants of customers.

We also found that gathering market information from other entities has no impact on market information quality, and this is contrary to our expectations. One reason for this situation could be the inclusion in a single group of several different entities such as distributors, suppliers or industry institutions which, as sources of market information, could impact its quality differently. Furthermore, these parties are usually less interested in NPD than customers or competitors are.
The results of this study provide empirical evidence that there is a partial mediation effect of market predictability that partially mediates between market information quality and new product financial performance. Firstly, our findings are in line with other studies, that showed that market information quality directly impacts new product performance (Hultink et al., 2011), and secondly, they additionally support partial mediation of market predictability in the following way: market information quality positively influences market predictability that, in turn, increases new product financial performance. Therefore, we showed an important economic implication of inputting market information in the NPD process.

Overall, this work supports an economic view that information can be seen as one of the most valuable production factors. Specifically, we observed that, in the area of new product development, market information is an important input that has economic consequences. Namely, obtaining market information from potential customers and competitors increases its quality, that, in turn, directly and indirectly - via market predictability - has a positive impact on the economic performance of a new product.

This study has several implications for new product practitioners. Our findings indicate that medium-high and high technology companies can enhance their new product financial performance by choosing potential customers and competitors as basic sources of market information. The key source that causes the increase of market information quality is customers. New product practitioners should obtain market information from potential customers several times and at different stages of a new product development project (Kahn, Barczak, \& Moss, 2006). This information may concern, for example, the needs, desires and preferences of customers, their buying behaviour, the importance of new product attributes, opinions about a new product concept, perceptions of competitors' products and satisfaction and loyalty to competing brands. Additionally, competitors are a valuable source of high-quality market information. This information may concern their new product strategies, present or future 
products and developments. This information can be obtained, for example, at fairs or through personal contacts, by monitoring rivals' behaviour or studying their products. Gathering market information from customers and competitors will result in having high-quality market information which, in turn, will lead to high new product financial performance, partly through market predictability.

The results and conclusions of this study have some limitations. Firstly, we relied on individual informants to give insights into constructs incorporated in the conceptual model. Because our informants were engaged in new product projects under consideration, there are good reasons to believe that they possessed knowledge about sources and quality of market information as well as market predictability and new product performance. However, it is possible that some respondents may have had incomplete information about some constructs of interest.

Secondly, our study focused on sources of information as antecedents of market information quality. Furthermore, some other constructs could affect this quality - for example, ways of obtaining market information. Future research should incorporate these dimensions and expand the conceptual model on, for instance, formal and informal ways of obtaining market information.

Thirdly, we concentrated on the medium-high and high technology industries in one country. Thus, the generalizations of the results are limited to our sampling frame. Further research could be carried out to test the conceptual framework across different industries and nations.

\section{Acknowledgements}

This study was performed under the research project 'Sources of market information and its quality and new product success.' The study was funded by the Faculty of Management and Economics, Gdansk University of Technology, on the basis of Contract No. DS/020352.

\section{References}

Barczak, G., Griffin, A., \& Kahn, K. B. (2009). Perspective: Trends and drivers of success in NPD practices: Results of the 2003 PDMA best practices study. Journal of Product Innovation Management, 26(1), 3-23. https://doi.org/10.1111/j.1540-5885.2009.00331.x

Barney, J. (1991). Firm resources and sustained competitive advantage. Journal of Management, 17(1), 99-120. https://doi.org/10.1177/014920639101700108

Birchler, U., \& Butler, M. (2017). Information Economics. Routledge.

Brown, T. A. (2015). Confirmatory Factor Analysis for Applied Research (2nd ed.). New York: The Guilford Press.

Cooper, R. G., Edgett, S. J., \& Kleinschmidt, E. J. (2004). Benchmarking best NPD practices-III. Research Technology Management, 47(6), 43-55. https://doi.org/10.1080/08956308.2004.11671662

Danneels, E., \& Kleinschmidt, E. J. (2001). Product innovativeness from the firm's perspective: Its dimensions and their relation with project selection and performance. Journal of Product Innovation Management, 18(6), $357-373$. https://doi.org/10.1111/1540-5885.1860357

Drejeriene, E., \& Drejeris, R. (2017). Systematic approach to a new service ideas conceptualisation: quantitative decision making. Inzinerine Ekonomika-Engineering Economics, 28(3), 323-333. https://doi.org/10.5755/j01.ee.28.3.14752

Durmusoglu, S. S., \& Barczak, G. (2011). The use of information technology tools in new product development phases: Analysis of effects on new product innovativeness, quality, and market performance. Industrial Marketing Management, 40(2), 321-330. https://doi.org/10.1016/j.indmarman.2010.08.009

Fornell, C., \& Larcker, D. F. (1981). Evaluating structural equation models with unobservable variables and measurement error. Journal of Marketing Research, 18(1), 39-50. https://doi.org/10.2307/3151312

Garcia, N., Sanzo, M. J., \& Trespalacios, J. A. (2008). New product internal performance and market performance: Evidence from Spanish firms regarding the role of trust, interfunctional integration, and innovation type. Technovation, 28(11), 713-725. https://doi.org/10.1016/j.technovation.2008.01.001

Hair, J. F., Black, W. C., Babin, B. J., \& Anderson, R. E. (2014). Multivariate Data Analysis (7th ed.). Edinburgh Gate: Pearson Education.

Henard, D. H., \& McFadyen, M. A. (2012). Resource dedication and new product performance: A resource-based view. Journal of Product Innovation Management, 29(2), 193-204. https://doi.org/10.1111/j.1540-5885.2011.00889.x

Hertenstein, J. H., \& Platf, M. B. (2000). Performance measures and management control in new product development. Accounting Horizons, 14(3), 303-323. https://doi.org/10.2308/acch.2000.14.3.303

Hu, L. T., \& Bentler, P. M. (1999). Cutoff criteria for fit indexes in covariance structure analysis: Conventional criteria versus new alternatives. Structural Equation Modeling, 6(1), 1-55. https://doi.org/10.1080/10705519909540118 
Hultink, E. J., Talke, K., Griffin, A., \& Veldhuizen, E. (2011). Market information processing in new product development: The importance of process interdependency and data quality. IEEE Transactions on Engineering Management, 58(2), 199-211. https://doi.org/10.1109/TEM.2009.2034254

Kahn, K. B., Barczak, G., \& Moss, R. (2006). Dialogue on best practices in new product development. Journal of Product Innovation Management, 23(2), 106-116. https://doi.org/10.1111/j.1540-5885.2006.00186.x

Kahn, K. B., Barczak, G., Nicholas, J., Ledwith, A., \& Perks, H. (2012). An examination of new product development best practice. Journal of Product Innovation Management, 29(2), 180-192. https://doi.org/10.1111/j.1540-5885.20 11.00888.x

Kelloway, E. K. (2015). Using Mplus for Structural Equation Modeling. A Researcher's Guide. London: Sage Publications.

Kline, R. B. (2016). Principles and Practice of Structural Equation Modeling. New York: Guliford Press.

Kuo, R. Z., \& Lee, G. G. (2009). KMS adoption: the effects of information quality. Management Decision, 47(10), 16331651. https://doi.org/10.1108/00251740911004727

Lee, Y. W., Strong, D. M., Kahn, B. K., \& Wang, R. Y. (2002). AIMQ: a methodology for information quality assessment. Information \& Management, 40(2), 133-146. https://doi.org/10.1016/S0378-7206(02)00043-5

Li, S., \& Lin, B. (2006). Accessing information sharing and information quality in supply chain management. Decision Support Systems, 42(3), 1641-1656. http://doi.org/10.1016/j.dss.2006.02.011

Lillrank, P. (2003). The quality of information. International Journal of Quality \& Reliability Management, 20(6), 691703. https://doi.org/10.1108/02656710310482131

Low, G. S., \& Mohr, J. J. (2001). Factors affecting the use of information in the evaluation of marketing communications productivity. Journal of the Academy of Marketing Science. https://doi.org/10.1177/0092070301291005

Millson, M. R. (2015). Exploring the nonlinear impact of organizational integration on new product market success. Journal of Product Innovation Management, 32(2), 279-289. https://doi.org/10.1111/jpim.12243

Moorman, C. (1995). Organizational market information processes: cultural antecedents and new product outcomes. Journal of Marketing Research (JMR), XXXII(3), 318-335. https://doi.org/10.2307/3151984

Muthen, L. K., \& Muthen, B. O. (2012). Mplus User's Guide (7th ed.). Los Angeles: CA: Muthen \& Muthen.

Naicker, V., \& Jairam-Owthar, D. (2017). The linkage of information quality to an executive decision support framework for the financial service sector of a developing economy. SA Journal of Information Management, 19(1), 1-9. https://doi.org/10.4102/sajim.v19i1.781

Ruzevicius, J., \& Gedminaite, A. (2007). Business information quality and its assessment. Inzinerine EkonomikaEngineering Economics, 52(2), 18-25. http://doi.org/10.5755/j01.ee.52.2.11470

Sagawa, J. K., \& Nagano, M. S. (2015). Integration, uncertainty, information quality, and performance: a review of empirical research. The International Journal of Advanced Manufacturing Technology. https://doi.org/10.1007/s00170-015$6836-5$

Wade, M., \& Hulland, J. (2004). The resource-based view and information systems research: review, extension, and suggestions for future research. MIS Quarterly, 28(1), 107-142. https://doi.org/10.2307/25148626

Warr, B., \& Ayres, R. U. (2012). Useful work and information as drivers of economic growth. Ecological Economics, 73, 93-102. https://doi.org/10.1016/j.ecolecon.2011.09.006

Woudstra, L., Van Den Hooff, B., \& Schouten, A. P. (2012). Dimensions of quality and accessibility: Selection of human information sources from a social capital perspective. Information Processing and Management, 48(4), 618-630. https://doi.org/10.1016/j.ipm.2012.02.002

Zha, X., Yang, H., Yan, Y., Liu, K., \& Huang, C. (2018). Exploring the effect of social media information quality, source credibility and reputation on informational fit-to-task: Moderating role of focused immersion. Computers in Human Behavior, 79, 227-237. https://doi.org/10.1016/j.chb.2017.10.038

The article has been reviewed. Received in October, 2015; accepted in February, 2018. 